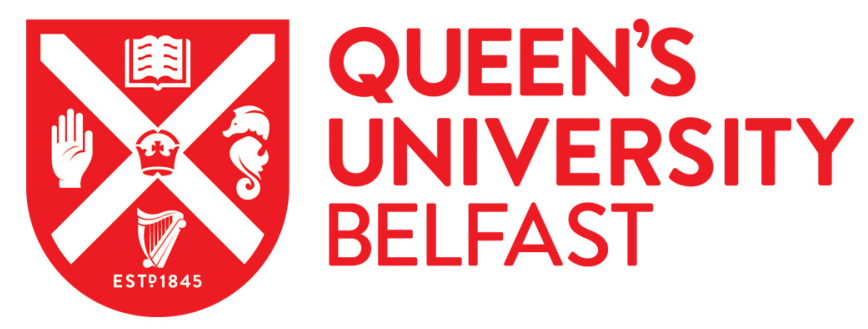

\title{
Mobilising of the German 1848 Protest Song Tradition in the Context of International Twentieth Century Folk Revivals
}

Robb, D. (2016). Mobilising of the German 1848 Protest Song Tradition in the Context of International Twentieth Century Folk Revivals. Popular Music, 35(3), 338-359. https://doi.org/10.1017/S0261143016000532

Published in:
Popular Music

Document Version:

Peer reviewed version

Queen's University Belfast - Research Portal:

Link to publication record in Queen's University Belfast Research Portal

Publisher rights

(C) Cambridge University Press 2016

This article has been published in a revised form in Popular Music http://dx.doi.org/10.1017/S0261143016000532. This version is free to view and download for private research and study only. Not for re-distribution, re-sale or use in derivative works.

\section{General rights}

Copyright for the publications made accessible via the Queen's University Belfast Research Portal is retained by the author(s) and / or other copyright owners and it is a condition of accessing these publications that users recognise and abide by the legal requirements associated with these rights.

Take down policy

The Research Portal is Queen's institutional repository that provides access to Queen's research output. Every effort has been made to ensure that content in the Research Portal does not infringe any person's rights, or applicable UK laws. If you discover content in the Research Portal that you believe breaches copyright or violates any law, please contact openaccess@qub.ac.uk. 


\title{
The Mobilizing of the German 1848 Protest Song Tradition in the Context of International Twentieth Century Folk Revivals
}

\begin{abstract}
The rediscovery of democratic traditions of folk song in Germany after the Second World War was not just the counter-reaction of singers and academics to the misuse of German folk song by the Nazis. Such a shift to a more 'progressive' interpretation and promotion of folk tradition at that time was not distinct to Germany and had already taken place in other parts of the Western world. After firstly examining the relationship between folk song and national ideologies in the nineteenth century, this article will focus on the democratic ideological basis on which the 1848 revolutionary song tradition was reconstructed after the Third Reich. It will look at how the New Social Movements of West Germany and the folk scene of the GDR functioned in providing channels of transmission for this, and how in this process a collective cultural memory was created whereby lost songs - such as those of the 1848 Revolution - could be awakened from extinction. These processes will be illustrated by textual and musical adaptations of key 1848 songs such as 'Badisches Wiegenlied' (Baden Lullaby), 'Das Blutgericht' (The Blood Court) and ‘Trotz alledem’ (For all that) within the context of the West German folk movement and its counterpart in the GDR.
\end{abstract}

\section{Introduction}

The period of the Vormärz (from the fall of Napoleon in 1815 up to March 1848) and the revolution of 1848-49 produced a wealth of political song-writing in Germany. It was an era of restoration, a particularly volatile political period in which broader 
sections of German society were striving for political emancipation from the princes and kings. A new oppositional political consciousness was reflected in the songs of the period which reflected themes ranging from freedom of speech and the need for democratic and national self-determination to critiques of injustice and hunger, and parodies of political convention and opportunism. A tradition of socially critical songs emerged, one that was marked by ruptures and sporadic revivals over the next century. In the Third Reich these songs were completely banned, causing them to fall into obscurity. But they did not die out entirely and were revived after the Second World War, firstly in the GDR by political song researchers and ethnomusicologists, and then in the 1960s by a new generation of folksingers in West Germany. The rebellious nature of the lyrics of the Vormärz and 1848 songs resonated with countercultural movements in both states who were keen to re-establish their own tradition of democratic songs of protest (Robb 2007a, pp. 11-33).

This rediscovery, however, was not just the counter-reaction of singers and academics to the misuse of German folk song by the Nazis. Such a shift to a more 'progressive' interpretation and promotion of folk tradition at that time was not distinct to Germany and had already taken place in other parts of the Western world. After firstly examining the relationship between folk song and national ideologies in the nineteenth century, this article will focus on the democratic ideological basis on which the 1848 revolutionary song tradition was reconstructed after the Third Reich. It will look at how the New Social Movements of West Germany and the folk scene of the GDR functioned in providing channels of transmission for this, and how in this process a collective cultural memory was created whereby lost songs - such as those of the 1848 Revolution - could be awakened from extinction. These processes will be illustrated by textual and music adaptations of key Vormärz and 1848 songs such 
as 'Badisches Wiegenlied’ (Baden Lullaby), 'Das Blutgericht' (The Blood Court) and 'Trotz alledem' (For all that) within the context of the West German folk movement and its counterpart in the GDR.

\section{The Shifting Ideologies of Folk Revivals}

In the revival of the German 1848 revolutionary song tradition after the Second World War, there were ideological processes at play which shaped the interpretation of this tradition in the present. The role of ideology has been the subject of much debate in folk song scholarship. Eric Hobsbawm, in his article 'Inventing Traditions', wrote about the fiction of continuity of much so-called 'tradition' with an historic past, which often presented a distorted reality and served a political purpose (1983). Eyerman and Jamison, in Music and Social Movements, take a more positive approach while emphasizing that a cultural basis must exist in the first place (1998, p. 38). Drawing on Raymond Williams' ideas on 'the selective tradition' (1977, p. 115) they discuss how lost traditions are never revived in a pristine form, but how an intentional shaping of the past occurs, influenced by an ideological standpoint in the present (p. 38). Using examples of pioneering folksong collectors such as Cecil Sharp who discovered the Appalachian Anglo-Irish ballads and John Lomax who researched the tradition of American cowboy songs, they note how such 'explorers' always have an agenda, be it theoretical, personal, commercial or political (p. 39). This is undoubtedly also the case with the revivalists of the tradition of 1848 song such as the folklorists of the early twentieth century and post-Second World War period in Germany as well as the German folk singers, groups and archivists in the folk revival of the 1960s onwards. 
Folksong research of the last few decades has often centred on the ideological dimension of folk song revivals. As Niall Mackinnon states, '[t]he desire to revive folk song is itself an ideological statement' (1994, p. 21). The example is frequently cited of the American Francis James Child, publisher of The English and Scottish Popular Ballads (1882-1898), whose views held great sway until well into the twentieth century. His criteria of balled selection (which excluded broadsides and American folk song) revealed an ideological approach in itself, one which has been accused of reflecting bourgeois class values (Harker 1985, pp. 101-120) and promoting 'the hegemony of the British ballad' (Bluestein 1972, p. 108). This continued in England in the early twentieth century with the fieldwork of Cecil Sharp, which centred round the search for a 'national music' (Mackinnon 1994, p. 22). It was intended to promote national unity and elevate the country's musical tastes (Cohen 2006, p. 29). In Germany, too, throughout the nineteenth and early twentieth century, the folk ballad had an ideological function in its need to demonstrate the 'Germanness' of folk music (Bohlman 2004, p. 183). The chief examples of this had been Achim von Arnim and Clemens Brentano's Des Knaben Wunderhorn. Alte Deutsche Lieder (The Youth’s Magic Horn. Old German Songs) from 1806 and 1808 and Erk and Böhme's three-volume Deutscher Liederhort (German Song Treasury) from 1893-1894. These formed part of a series of 'monumental' ballad collections which, according to Bohlman, promoted the German national myth 'at those moments when there was a particular need for national repertories and canons of German music' (p. 187): Des Knaben Wunderhorn in the decades after the Enlightenment when the idea of the modern German nation was taking shape, and Deutscher Liederhort in the decades after national unity of 1871. A national song project which stamped the Third Reich was Deutsche Volkslieder mit ihren Melodien (German Folk 
Songs with their Melodies) edited by John Meier and colleagues at the German FolkSong Archive (DVA), whose first volume appeared in 1935 (p. 189). A separate DVA project in the Nazi period was the 'Landschaftliche Lieder' (Landscape Songs), begun in 1924 with the backing of the Association of German Folklore Societies. The selected songs, which included songs in German-speaking areas of Europe such as Slovenia and the Ukraine, 'relied on a national sense of sonic authenticity basic to folk songs in the German language' (Bohlman 2004, p. 65). Bohlman argues that cementing the nationalist dimension of folk song in this way at institutional level during this period left the project open to accusations of 'complicity' with the Third Reich (p. 142).

A later pivotal moment in the history of German ballad reception was Wolfgang Steinitz's Deutsche Volkslieder demokratischen Charakters aus sechs Jahrhunderten (Six Centuries of German Folksongs of Democratic Character), the first volume of which was published in the Aufbau (construction) years of the GDR in 1955. This was a German socialist take on 'a six-century course of nationalism that had reached its apex with the founding of the GDR' (Bohlman, p. 71). As will be examined, this was to have a profound stimulus on the revival of German democratic folk songs from the 1960s onwards.

As Bohlman states, however, the influence of nationalism on folksong has not always come from the top down, i.e. from state institutions and ideologies (p. 11). The two have been coupled together since Johann Gottfried von Herder promoted folksong as the source where Germany could access the roots of its own culture (Herder 1778 and 1779; Bluestein 1972, p. 6). The new idea, emanating from the Enlightenment, that "'the voices of the people” were audible in songs (Bohlman 2004, p. 42) coincided with the emerging notion of the nation state and the people's 
role in shaping this. Herder's progressive idea has often been misinterpreted as nationally chauvinistic, especially since the Nazis’ misuse of Volkslieder ${ }^{1}$. But, as Bohlman argues, the political impulses in national folksongs are more difficult to pigeon-hole. Nationalism in Europe, he says, 'has many shades' (p. xxvi). It 'accompanies a long history of complex multiculturalism [...] and subaltern resistance to the hegemony of the nation-state' (p. xxiii). It 'may build its path into music from just about any angle, as long as there are musicians and audiences willing to mobilise cultural movement from these angles' (p. 11). We see these different shades of nationalism in the history of reception of the songs of the Vormärz and the 1848 Revolution. Whether the workers' movement of the late nineteenth century, the political song culture of the Weimar Republic or the folksong revivals of the twentieth century, these songs had oppositional connotations at the same time as having a national agenda. Significantly, however, in terms of which songs from this tradition were revived in each of these periods, the aforementioned aspect of selection can be seen to apply.

At the time of the 1848 revolutions throughout Europe there had been an 'explosion of national songs' because revolution was linked to nation building. As Bohlman writes, 'citizens [had] come to recognise the potential of taking nationalism into their own hands' (p. 55). However, precisely because this nationalism threatened the hegemony of the rulers in their kingdoms and principalities throughout Germany, most of these socially critical songs were silenced during the Vormärz and after the failed revolution (see Robb and John, 2013). At the same time, the reception in the late nineteenth century, particularly in the context of the rise of the workers' movement from around 1870 onwards, demonstrates efforts (albeit arguably halfhearted) to integrate this socially critical tradition into a wider repertory of German 
songs. Ditfurth’s collection Die historischen Volkslieder der Zeit von 1648 bis 1871 (The Historical Folksongs of the Period from 1648 till 1871), which appeared in 1871-1872, the first years of German unification, is one example. It included songs dedicated to Friedrich Hecker, the popular insurgent who had led the Baden uprising of April 1848 which was put down by government troops. Hecker had fled to America and subsequently become a cult figure throughout Germany. The imagery of 'Hail Hecker!' reflects the man's status as a popular national hero prepared to sacrifice himself for his country: 'Hecker! May your name resound loudly / Along the whole German Rhine! / Your loyalty, yes your eye / Instils trust in us all. / Hecker! The German man / Who would die for freedom. ${ }^{2}$

The Ditfurth volume also contained socially critical songs less nationalist in orientation, but nonetheless dealing with popular issues of the 1840 s such as 'Der Bürgermeister Tschech' (The Mayor Tschech), the lampooning of a botched assassination attempt on the King of Prussia in 1844, 'Freifrau von DrosteVischering', a satire of the power of the Catholic Church, also from 1844. Another volume of the Kaiserreich period, Hoffmann and Prahl's Unsere volkstümlichen Lieder (Our Traditional Songs) from 1900, included 'Das Bürgerlied' (Citizen’s Song), the popular anthem from 1845 reflecting the emerging German bourgeoisie’s sense of democracy and the power to shape their own destiny:

Whether we wear red or yellow collars,

Hats or helmets

Boots or shoes;

Or whether we sew jackets

Or put the wires in shoes

It's all the same what we do 


\section{$[\ldots]$}

But whether we build something new

Or just chew the old cud

Like a cow does grass

Or whether we do something for the world

Or just gape at the world

It's not all the same what we do (see Widmaier, 2008)

However, these instances of reception are the exception rather than the rule. The bulk of the socially critical songs from the Vormärz and 1848 Revolution were ignored, indicating a suppression of this tradition. These included the anonymous 'Fürsten zum Land hinaus!' (Princes Get Out!), a playful but antagonistic anti-monarchist song from 1832 whose suspected authors were pursued by police for several years (see Robb and John 2013). Another is Ludwig Pfau's 'Badisches Wiegenlied' (Baden Lullaby), a mother's plea to her child to take revenge on the Prussians for their reprisals after the crushed Baden uprising of 1849.

Even the nationalist songs of 1848 were largely ignored in the second half of the nineteenth century. Prominent examples of these, highly nationalist in their symbolism but disregarded by song collectors, were those dedicated to Robert Blum. The Frankfurt Assembly member Blum had been executed by Austrian Kaiser's troops for his involvement in the Vienna October uprising of 1848, after which he became a German national hero and revolutionary martyr. Songs such as 'Was zieht dort zur Brigittenau' (The Procession to Brigittenau) and ' $\mathrm{O} D \mathrm{Du}$ verratnes Deutschland' (Oh you betrayed Germany) contain strong nationalist imagery depicting Blum as having died for his German fatherland. The latter begins with the verse: 'Oh you betrayed Germany! / Your shrine is abandoned! / Your Robert has 
been shot, / Your loyal Robert Blum! / Freedom sent out many heroes / To fight and struggle for the Fatherland / For our German, German land!' The former concludes: 'The officer cadet is killed / Robert Blum has fallen: / Rise up brothers to save the flag, / Freedom from shackles and chains / For the good of Germany' (see Robb and John 2008-2013).

The Blum songs, some of which were widely sung in 1848-1849, completely disappeared from view until they were rediscovered by folklore researchers in the first decades of the twentieth century (e.g. Wirth, 1928; Schewe 1930; Heeger 1938). ${ }^{3}$ The fact that none appear in any prominent German song collections before Steinitz indicates the extent to which they had fallen into obscurity. The history of reception of 'O Du verratnes Deutschland' reveals an incident in the period 1848-1849 which points towards the repression of this song culture, whereby teachers at a school in Chemnitz were interrogated by police on suspicion of having taught pupils this song. It was revealed, however, that the children had learned it outside of school, an indication of its popular circulation at the time (Willert 1960, p. 27).

Other Vormärz and 1848 songs, nationalist in orientation, which were largely ignored in song and poetry collections of the nineteenth century are those by Ferdinand Freiligrath, Georg Herwegh and Heinrich Hoffmann von Fallersleben. In the history of reception right up to Steinitz these have mostly been treated as political poetryas opposed to Volkslieder despite evidence that some of their texts had been set to music in the 1840s. ${ }^{4}$ A famous example is Freiligrath's 'Schwarz-Rot-Gold' (Black Red Gold). This celebrates the flag colours of a new democratic German nation at the outset of the March 1848 revolution. As this verse reflects, the idea of German nationhood is presented in anti-monarchical, republican terms: 'Freedom is the nation! / Demanded of all equally! / Freedom is the auction / Of thirty princes’ hats! / 
Freedom is the republic! / [...] / Powder is black, / Blood is red, / Golden flickers the flame!' Set to music by several composers in 1848 including Robert Schumann, this song fell into obscurity thereafter, not making a reappearance until 1902, as a poem in Petzet’s lyrical anthology Die Blütezeit der deutschen politischen Lyrik von 18401850 (The High Period of German Political Lyric from 1840-1850). In the 1920s, 'Schwarz Rot Gold' became the standard-bearing song of the social democratic Reichsbanner Schwarz-Rot-Gold, one of the republican protection groups formed in response to the emergence of right-wing paramilitary groups (see Robb and John, 2008-2013).

The liberal nationalist poet Hoffmann von Fallersleben is, of course, famous for his popular 'Lied der Deutschen' (Song of the Germans) from 1841 which was set to music by Haydn in his Op. 77 Quartets and, with its line 'Deutschland, Deutschland über alles', was misappropriated by the Nazis a century later to support their German hegemonic aspirations in Europe. He is also known for his 1842 adaptation of the late-eighteenth century anti-censorship song 'Die Gedanken sind frei' (Thoughts are Free), which had already appeared in the third volume of Des Knaben Wunderhorn (1808). At the time of the 1848 Revolution, however, Hoffmann von Fallersleben was for the most part silent except for his text 'Ausgelitten, ausgerungen' (Long Suffering and Wrung Out), set to the tune of 'Guter Mond du gehst so stille’ (Good Moon You are so Peaceful) (see Robb and John 2013). It was similarly satirical in style to Herwegh's 'Mein Deutschland, strecke die Glieder' (My Germany Stretch Your Limbs), both of which were written towards the end of the revolution, and lament the failures of the bourgeoisie in wrestling power from the establishment. Unlike 'Schwarz-Rot-Gold', these songs did not enjoy much circulation during the 1848-49 period itself, but their lack of publication thereafter, 
too (other than in poetry collected editions of the respective authors), confirmed the trend: it was not until 1930 in the Weimar Republic, in the context of revived interest in revolutionary lyric, that all three of the above poems were published in a separate 1848 collection, namely Underberg's Dichtung der ersten deutschen Revolution (Poetry of the First German Revolution).

After these intermittent revivals of German democratic folk song between 1870 and 1933 - in workers' song pamphlets, folklore studies and revolutionary poetry anthologies - the advent of the Third Reich caused a clean rupture with this tradition. The Nazis' ideological appropriation of the folk song tradition was so thorough that subsequent generations of both post-war states struggled to overcome this legacy of nationalist association. One of the main problems for the German revival of the 1960s was the association of folksong with political conservatism in the minds of the public. Up until the present day, many Germans understand Volksmusik as the 'volkstümliche Lieder' (folksy songs) they see on prime-time TV shows such as Musikantenstadl. In the 1950s and 1960s this escapist and nostalgic-restorative type of song was oriented towards the concept of Heimat (home) which had been promoted in popular post-war film (Adamek-Schyma and Tzschaschel, 2006). This folksy genre often overlapped with Schlager, the popular commercial German songs containing superficial lyrics set to basic beats and sing-along melodies. As a result, the early folksong revivalists of the 1960s found the cultural sphere of Volkslieder to be 'okkupiert' - by Nazis in the past and by such TV programmes in the present (Nate 1994, p. 86) ${ }^{5}$ to the extent that most democratically minded Germans completely shunned their own folksong tradition Franz Josef Degenhardt (1968) famously sang 'wo sind die Lieder/ unsere alten Lieder' (where are the songs / our old songs?). In this respect the reconnecting with the democratic songs of German 
folksong heritage, including those of the 1848 Revolution, firstly by Peter Rohland at the Burg Waldeck Festival of 1965, was a conscious distancing from the nationalist repertoire of folksongs and their reactionary connotations. Rohland's revival of the 1848 songs was highly influenced by Steinitz's aforementioned Deutsche Volkslieder demokratischen Charakters. ${ }^{6}$

Steinitz's collection and the new orientation of the folk singers, however, should not be seen as isolated German occurrences, but in conjunction with international trends. The Second World War had had a profound impact on ideological approaches towards folk music. The Steinitz collection, with its emphasis on the folksongs of the werktätigen (workers), was an example of post-war 'attempts in the study of traditional music to broaden and reformulate previous ways of ascribing and describing cultural identity’ (Bohlman 1988, pp. 36-37). ${ }^{7}$ The midtwentieth century had already seen a trend in the USA and Britain towards an ideological emphasis on the democratic roots of folk song cultures. The roots of this lay in a development which began in the early twentieth century. In response to the perceived hegemony of the British ballad, American academics and collectors had set out to discover a distinctively American folk literary culture. From 1910 onwards, John Lomax collected and published songs from a wide cross-section of American society ranging from black people, miners, lumbermen and railroaders to down-andouts and desperados (Bluestein 1972, pp. 97-98). In the 1930s and 1940s, together with his son Alan, John Lomax published songbooks such as American Ballads and Folksongs (1934), Negro Folk Songs as sung by Lead Belly (1936) and Folk Song USA (1947). The flood of research in American folksongs resulted in the support of the federal government. This came as part of the programme of President Roosevelt's New Deal which, in the wake of the Wall Street Crash and the subsequent 
Depression, promoted a healthy environment for the appreciation of American folk culture (Cohen 2006, p. 49). The Archive of American Folksong was founded in 1928 with John Lomax as honorary curator from 1932 and his son as Director from 1937. Another influential protagonist was the ethnomusicologist Charles Seeger, father of singer Pete Seeger, who ran the Federal Music Project in the archive from 1937-1941. During this period Alan Lomax, who ran the Archive of American Folksong of the Library of Congress, introduced a national radio audience to singers such as Woody Guthrie, Pete Seeger and Huddy Ledbetter (Leadbelly) and their songs about civil rights, trade unions and the disenfranchised. This search in songs for 'the nature of the American character' had a clear national agenda, but now with a twist whereby, as Bluestein (1972, p. 105) notes, 'a democratic ideology [emerged] which stressed the virtues of the common man and the dignity of oppressed groups'. For John Lomax himself, this ideology was contained in the sentiment of 'A Man's a Man for a' that' by Robert Burns from 1795:

This is the big theme of American folk song, running through all the songs - the theme stated by Burns’s '...A man's a man for a' that' and even more powerfully in the Negro ballad 'John Henry’. A man ain’t nothin’ but a man... (Lomax 1947, p. v.iii).

The values of freedom and emancipation which Burns' song symbolized when written six years after the French Revolution, mirrored those of the American Bill of Rights of 1789. In the USA, against the background of the Depression, activity of trade unions, the development of grass-roots democracy and the international fight against Fascism, these values were reinvigorated and expressed in the context of a folk song movement. 
It is highly significant how the spirit of the American folk movement attracted young musicians in both parts of Germany in the 1960s. The banjo-playing Canadian Perry Friedman introduced the first Hootenanny evenings in East Berlin in 1960. The Hootenannies were the collective music-making evenings originally promoted in the USA by the Almanac Singers (featuring Lee Hays, Pete Seeger and Woody Guthrie) in the context of the Popular Front of the early 1940s. One of the attractions for the East Germans was Friedman's uninhibited way of singing and playing and the informal setting which clashed with the more disciplined associations of German folk-singing. At Friedman's GDR Hootenannies, Anglo-American and international protest songs were sung alongside German folk songs (Böning 2004, p. 201; Kirchenwitz 1993, pp. 27-35), creating the model which came to characterise the GDR Singebewegung which emerged later that decade albeit with its greater ideological pro-state remit (see Robb 2007b, pp. 227-235).

In the 1960s in West Germany, too, the nation's efforts to distance itself from the Nazi legacy and embark on a new democratic path resulted in a young generation of folk singers embracing the spirit and ideology of the American folk movement. At the anti-nuclear Easter Marches in West Germany of the early 1960s the singing of German texts to the melodies of songs such as "Down by the Riverside" and "We Shall Overcome” reflected this influence (Böning 2004, p. 53). Distinct from the conservative, nationalist folksong movements of the early twentieth century, these songs embodied a rebellious folk tradition, the like of which was previously unknown to most Germans.

The Burg Waldeck Festival from 1964-1969 was the breeding ground of the new West German political and folksong. Despite an orientation of the new brand of Liedermacher such as Franz Josef Degenhardt towards the political French chanson in 
the style of Georges Brassens, many others including Hannes Wader increasingly veered towards the gestus of the American and the British folk protest song. One of the early guests at Waldeck was the English folksinger Colin Wilkie who inspired local Germans with the finger-picking folk guitar technique that Woody Guthrie had popularised (Holler 2007, p. 104). After visiting the Newport Folk Festival in 1967 Waldeck’s festival director Rolf Gekeler booked the American singers Phil Ochs, Odetta and Guy Carawan for the following year (Holler, p.119). All were political activists, Ochs known for songs such as ‘I Ain’t Marchin’ Anymore’; Odetta a leading voice in the civil rights movement; Carawan was a musical director at the Highlander Center (formerly known as the Folk School) in Tennessee and credited with introducing 'We Shall Overcome' to the American movement in 1960 (Cohen 2006, p. 151).

Inspired by such libertarian influences, a new hybrid German folk and protest song genre emerged henceforth, developed by the likes of Hannes Wader and Walter Mossmann. It was not coincidental that the song 'Trotz alledem,' the German adaptation of Robert Burns’ aforementioned ‘A Man’s a Man for a’ that,' struck the nerve of the time and became the most recorded song of the West German folk revival (Robb and John 2011, pp. 17-46).

\section{The 'selective tradition' of 1848 Songs}

From 1849 up until after the Second World War, the songs of the 1848 Revolution did not take hold in Germany. As the history of reception shows, the 1848 Revolution was politically contested, its songs either prohibited or forgotten, resurfacing at intermittent points in the subsequent century (Robb and John 2013). After the Second World War in the communist GDR, however, a reconnecting with 'progressive' 
German cultural traditions occurred straight away and was conducted in a systematic way at an official level. ${ }^{8}$ This was evident in the promotion of the German worker's song by Ernst Busch in the late 1940s and Ingel Lammel, musicologist and song researcher in the Arbeiterliedarchiv (Workers Song Archive), founded in East Berlin in 1954. In the attempt to construct a culture of memory by promoting continuity with a revolutionary past, one comes across the aforementioned idea of the 'selective tradition'. An example of this can be seen with regard to the song 'Trotz alledem' (For a' that), which appeared in Busch's collection Internationale Arbeiterlieder in 1949. Ferdinand Freiligrath had written two versions of 'Trotz alledem', the first in 1843, a direct translation of Burns' text, the second an adaptation written in 1848 specifically for the revolution with the opening line 'Das war 'ne heiße Märzenzeit' (That was a hot time in March). It is the latter which Busch uses here, set to the same accompaniment ('Lady McIntosh’s Reel') as the Scottish song. ${ }^{9}$ Responding to the return of political reactionarism despite the initial successes of the March 1848 revolution, the German text draws on the utopianism and spirit of defiance contained in the original poem by Burns: ${ }^{10}$ :

It was a hot time in March,

For the rain, snow and all that!

But now that it's snowing blossom,

It is cold, for all that!

$[\ldots]$

Yet we are fresh and in good form, And won't give up hope for all that!

The rage glows deep within our hearts, And keeps us warm for all that! 
For all that and all that -

For stupidity, tricks and all that,

We know humanity will be

Victorious for all that!

Busch ends on an upbeat note, adding the final verse of Burns' original poem to the Freiligrath adaptation of 1848:

Then let us pray that come it may,

As come it will for a' that,

That Sense and Worth, o'er a' the earth

Shall bear the gree, and a' that.

For a' that, and a' that,

Its comin yet for a' that,

That Man to Man the warld o’er,

Shall brothers be for a' that. ${ }^{11}$

The particular selection of verses in this version appears ideologically motivated. What is significant is the montage of various parts of different verses of Freiligrath's 1848 adaptation as well as the unexpected inclusion of the last verse of Freiligrath's 1843 translation with its utopian conclusion. It is possible that this montage points to a vibrant oral tradition in international circles of the socialist movement in which Busch had moved since the 1930s. ${ }^{12}$ It seems more probable, however, that this new version was created in accordance with the ideological spirit of the time, that is, the Aufbau (construction) period of the new socialist GDR. It is apparent that the choice 
of verses is restricted to those with an optimistic and utopian content, while the ones expressing disappointment at the return of the reactionary forces are left out. It is moreover clear that Busch’s songbook itself was conceived primarily for practical use amongst workers and the GDR youth for the moulding of a socialist consciousness.

A similar ideological motive was undoubtedly behind the versions appearing in the pamphlet Lieder der Revolution von 1848, edited by Inge Lammel, where both Freiligrath adaptations appear alongside each other (1957, pp. 12-15). The selection of twenty-two songs in this pamphlet conveys the euphoric spirit propagated by the Socialist Unity Party (SED) in that period. Most reflect the pathos of victory, defiance, and the appeal to fight, as in Wilhelm Jordan’s 'Nicht länger war das Joch zu tragen’ (No Longer was it Possible to Carry the Yoke), Heinrich Bauer’s 'Aufruf!' (The Call!), and the anonymous 'Freiheits-Marsch’ (Freedom March). Other songs employ the characteristic 1848 slogan 'Aufwachen!' (Wake Up!), for example Freiligrath’s ‘Reveille’ and Herwegh’s ‘Frühlingsmorgenruf’ (Spring Morning Call). This was to contrast with the rather downbeat treatment of the 1848 song tradition three decades later in the GDR, which tended to emphasize the theme of revolutionary defeat, as will later be exemplified in relation to the group Wacholder's interpretation of 1848 songs in the 1980s (Robb 2007B, pp. 18-26).

Further publications of 1848 songs in the GDR included influential collections by Bruno Kaiser (1952) and above all Wolfgang Steinitz’s seminal volumes Deutsche Volkslieder which included a substantial section on Vormärz and 1848 songs. Although Steinitz's research initially had little popular impact in the GDR itself, it had an immediate effect in the early to mid-1960s in West Germany where the young Peter Rohland introduced the concept of democratic folk songs to an audience at the 1965 Burg Waldeck festival. Here the former youth movement singer called for an 
overhaul of the old romantic perception of German folk song with its nationalistic overtones: 'We have to finally correct this concept. German folk songs neither represent "the soul of the people” nor "eternal values". They are simply songs which embrace the whole aspect of human life' (Rohland, quoted in Probst-Effah 1995, p. 18).

Despite minimal initial interest - Rohland's concert of 1848 songs took place in the low-key setting of a workshop - the genie of democratic folk song had been set free: Rohland's LP Lieder deutscher Demokraten (Songs of German Democrats) was released in 1967 (Rohland 1967) a year after his tragically premature death. Other early cases of reception include Fredrik and Uli's recording of Ludwig Pfau's 'Badisches Wiegenlied' (Baden Lullaby) (1968), a song about the aftermath of revolutionary defeat in Baden in 1849. By the early 1970s the 1848 song repertoire was being adopted by increasing numbers of folk groups and Liedermacher. This was reflected by the further release of LPs and cassettes of Vormärz and 1848 songs by singers and groups such as Dieter Süverkrüp (1973), Hein and Oss Kröher (1974), Fortschrott (1980), and other artists. ${ }^{13}$

The selective approach to tradition was also evident here, whereby it becomes clear that certain types of 1848 songs are preferred over others. Reasons for this vary from current trends in musical style to the ideological associations of the songs. A case in point is the pathos-laden battle hymns such as the aforementioned Robert Blum and Friedrich Hecker songs 'Was zieht sich zur Brigittenau' and 'Hecker Hoch!' While these were acknowledged since Steinitz as important 1848 songs, they were not popular choices among the singers and groups of the folk revival. The reasons for this are various. Musically, the militaristic gestus of these battle hymns was simply not palatable for the mostly pacifistic groups and Liedermacher, who in 
the 1960s and 1970s identified more with European and North American folk-singing styles and modern popular musical accompaniments. In this respect a major criterion of reception was how easily a song leant itself to the new folk idioms of the current music world. But also on an ideological level, the pathos of these tributes to Blum and Hecker did not resonate with members of the young countercultural generation. After the experiences of the Third Reich, the youth were unlikely to identify with such pledges of unconditional belief in political icons. Thirdly, the aforementioned German nationalist aspect of the Blum and Hecker songs would have been suspicious to the alternative youth, who clearly wanted to distance themselves from the romantic notions of a German fatherland, irrespective of whether they had been intended in a progressive way in 1848. By the same token, this was clearly a double-edged association: as will later be examined, it was precisely the national aspect of the 1848 song repertoire which allowed it to be appropriated by central Federal institutions in the 1980s, keen to promote a new democratic image of Germany.

If, for the performers of the folk revival, pathos was out, critical irony was in. Examples of well received songs were Georg Herwegh’s ‘Wohlgeboren’ (Well Born), a satire of bourgeois opportunism, and 'Das Reden nimmt kein Ende' (The Talking Never Stops), a song mocking the 1848 Frankfurt assembly's inability to make decisions. Subversive street ballads such as the anonymous 'Bürgermeister Tschech', which lampoons a botched assassination attempt on the King of Prussia in 1844, was also popular, in conformance with the rebellious spirit of the 1968 student generation (see Robb and John 2008-2013).

Above all, singers and groups latched on to songs where historical parallels could be drawn with the present. Peter Rohland, for example, highlighted the theme of post-revolutionary retreat into subordination as expressed in Herwegh's 'Mein 
Deutschland, strecke die Glieder’ and Hoffmann von Fallersleben’s 'Ausgelitten, ausgerungen'. This was significant for a 1960s audience in view of the perceived atmosphere of conservative restoration that gripped an affluent West Germany in the years after the Economic Miracle (Robb 2007B, p. 46). Among the most widely recorded songs were Freiligrath’s 1848 adaptation of 'Trotz alledem’ (For a’ that), which voiced the spirit of eternal defiance despite the circumstances, and the anonymous 'Blutgericht' (The Blood Court), a bitter attack on capitalist structures of hierarchy and exploitation. Particularly in the GDR the court verdicts and torture related in the first two verses could have been interpreted in relation to the perceived lack of justice.

\footnotetext{
A blood court is what we have here,

Harsher than Vehmic law

With verdicts cruelly more severe

Than death plain, swift, and raw.
}

Relentless torture is our fate,

And we are on the rack.

Hear our sighs from morn to late

While they are on our back. ${ }^{14}$

Another highly popular song was the aforementioned 'Badisches Wiegenlied' whose theme of sleep in the first line of each verse 'Schlaf mein Kind schlaf leis' (Sleep My Child, Sleep Softly) suggested itself to West German singers as a metaphor for the political stagnation of the Adenauer period, in particular the retreat into an inner, private world as a consequence of political repression: 
Sleep my child, sleep softly,

The Prussian is outside!

He’s killed your father,

He’s made your mother poor,

And if you don’t sleep peacefully,

The Prussian will close your eyes for you.

In this respect its performance by the duo Fredrik und Uli (Fredrik Vahle and Ulrich Freise) at the International Essen Song Festival in September 1968 served as an example of how the modern adaptation of such historical texts could transform them into 'brand-aktuelle Kampfsongs von überzeugender Musikalität und Dramatik' (brand-new protest songs, convincing in their musical and dramatic effect) (Mahnert and Stürmer 2008, p. 124). Against the background of the student movement and the West German government's introduction of the Emergency Laws, these songs took on a special significance as an expression of political protest.

\section{Channels of Transmission in the New Social Movements}

From 1849 up until after the Second World War, the songs of the 1848 Revolution did not take hold in Germany. As the history of reception shows (see Robb and John 2008-2013), the 1848 Revolution was politically contested, its songs either prohibited or forgotten, resurfacing at intermittent points in the subsequent century. It was not until the New Social Movements of the 1970s in West Germany that a collective awareness of a 'tradition' of those songs emerged. This contrasts with clear, unbroken traditions of cultural memory such as that of the Jacobite rebellions in Scotland or the 
1840s famine in Ireland, whose narratives have been handed down - partly in song over generations.

The fact that the 1848 songs did not die out, however, is significant. Rosenthal and Flacks, in their book Playing for Change: Music and Musicians in the Service of Social Movements, write about how the 'portable' nature of music and songs allow them to be affirmed and reaffirmed 'even in the absence of movement activity' (2012, p. 126). This was evident, for example, with the rupture to the American folksong movement by McCarthyism in the 1950s leading to these songs having to be rediscovered by a new generation in the 1960s. As Todd Gitlin remarked: 'The Popular Front was dead, but the idea of it could be sung' (1987, pp. 75-76). While the rupture in German culture was deeper and more systematically carried out by the Nazis, there are nonetheless comparisons. In Germany the 1848 songs lived on, too, not in collective memory, but in isolated memories of older workers and in the research of ethnomusicologists and literary scholars. This article will later investigate how the new social movements of West Germany, through collaboration between singers, academics, political activists and a folk music industry provided a channel by which the memory of the 1848 revolutionary tradition could be mobilized and its songs re-activated.

The New Social Movements were left-wing initiatives which emerged in the wake of the student rebellion of the late 1960s. In this respect, the German folk revival mirrored its American counterpart in its location within a social movement that can be used to channel tradition. Eyerman and Jamison describe how art and music play an important role in this process whereby individual and collective identities can be formed (1998, pp. 21-22). This was a feature of the collective and participatory singing of the 'Hootenannies', just as the singing of civil rights songs 
such as 'We Shall Overcome', 'We Shall Not Be Moved' or 'Which Side Are You On?' reflected the 'ritual of performance' which can 'empower, help create collective identity and a sense of movement in an emotional and almost physical sense' (1998, p. 35). In the New Social Movements in West Germany certain songs epitomised this same function. One example is Hannes Wader's 'Wir hofften in den 60ern' (We had hopes in the 1960s) from 1977, a parody adaptation of Freiligrath's 1848 version of 'Trotz alledem'. This plays on the contradiction of the title phrase to bemoan the lack of genuine liberty - despite (for all) the German Constitution, the student movement of the late 1960s, and the coming-to-power of the Social Democrats in 1972. The live recording is a good example of how a politically engaged utility song works in its particular social and historical context. Hannes Wader, accompanying himself using the guitar finger-picking technique adopted from the American folk revival, sings to an audience that hangs on enthusiastically to every word and sings along. The audience - predominantly sympathizers of the left and supporters of the DKP (German Communist Party) alongside Wader fans - cheer at the new variations in the choruses, above all at the lines referring to the hated Social Democratic Party ('Trotz SPD und alledem') and the 'Berufsverbot' (ban preventing Communist Party members working in the Civil Service): 'Trotz Grundgesetz und alledem / drückt man uns mit Berufsverbot / die Gurgel zu trotz alledem' (For constitution and all that / they suffocate us with the work ban law for a' that) (Wader 1977). The recording thus conveys the ritualistic, emotional aspect of the performance in its setting - that is, the intensity of the sentiments expressed against the West German establishment. ${ }^{15}$

The ability of an audience to identify emotionally and intellectually with a song reflects what Eyerman and Jamison term 'cognitive praxis'. This is the acquisition of historical and cultural knowledge necessary to understand a tradition, to 
identify with it and to disseminate it further (1998, pp. 20-25). In a social movement this is brought about by an interrelationship between academics, practitioners and activists. In the USA, the academic research of the Lomax and Seeger families provided the cognitive tool for many a practitioner. There was also the Highlander Centre (formerly known as the Folk School) in Tennessee, a meeting place for singers and activists from the 1940s onwards. Such an interplay was able to cross generations and thus further the nurturing of collective memory within the social movement (Eyerman and Jamison 1998, pp. 120-121; pp. 160-162). This was a creative acquisition of tradition, as seen in the social movement context of the 1960s, where young artists such as Bob Dylan, Joan Baez and Phil Ochs picked up and reworked the tradition established in the previous decades by their predecessors, Pete Seeger, Woody Guthrie and others.

Such a cross-generational relationship also characterized the German folksong movement. Drawing on academic research of their elders, particularly that of Steinitz, singers like Peter Rohland were able to renew their knowledge of German Volkslieder which they had established as teenagers in the Jugendbewegung (Youth Movement) (Holler 2007a, pp. 97-103). In the 1970s and 1980s this was further augmented by ongoing contemporary research which used the Deutsches Volksliedarchiv in Freiburg as a resource. One example was Ulrich Otto’s Die historisch-politischen Lieder und Karikaturen des Vormärz und der Revolution von 1848/1849 from 1982. . The DVA librarian Barbara James was a well-known networker within the folk scene and also a highly respected song collector. Examples of festivals and workshops she organised in conjunction with folk singers and academics were the 'Festival deutsches Volkslied' (Festival of the German Folksong) in Freiburg in 1977 and 'Geschichte in Liedern' (History in Songs) in Kiel in 1979. Together with Walter 
Mossmann, she published Glasbruch 1848. Flugblätter und Dokumente einer zerbrochenen Revolution (Broken Glass 1848. Broadsides and Documents from a Broken Revolution) (1983), which interprets key 1848 songs from the perspectives of travelling journeymen, soldiers, political émigrés and other social groups involved in the revolution.

Such a relationship between academics and practitioners was mutually beneficial. Many professional folk singers used the DVA as a resource for the songs they performed. ${ }^{16}$ Armed with his historical knowledge of the protest folksong, Walter Mossmann revamped the German Volkslied tradition with new parody texts and modern styles of musical accompaniment. An example was his new version of 'Badisches Wiegenlied' in 1977. On one hand the original song was viewed as a historical document in its direct expression of the military defeat of the 1848-49 revolution. But over and above that, the song also represented a bridge to the present: 'der Preuß’ (the Prussian) continued to function as a symbol of repressive authority. But not just content with a metaphorically charged historical allusion, Mossmann wrote an additional verse which took a clear stance on a current political debate: that of the continuing political influence of former members of the Nazi Party. It criticises Hans Karl Filbinger, former Nazi and at the time Minister-President of the state of Baden Württemberg, a position he held from 1966 to 1978. Mossmann plays the song to the popular folk tune of 'Schlaf Kindchen, Schlaf' (Sleep My Child, Sleep), but defamiliarises this to such an extent, singing in a staccato style reminiscent of the highly influential dissident GDR Liedermacher Wolf Biermann ${ }^{17}$ that a new version emerges, suitably expressing the unease inherent in the text (Mossmann 1977). 
Over a hundred years ago.

The Prussian is now old hat,

But the old rage has remained

Towards anyone with power and money

Who holds the land of Baden in a vice.

Get up my child, it’s burning,

we need a thousand hands.

The new Prussian, everyone knows

Is the leader of the Federal state.

From the late 1960s onwards, the social movement forming around the folk revival was supported by record labels, music clubs, festivals and fanzines. The independent labels included Pläne from Dortmund, whose artists included Hannes Wader, Dieter Süverkrüp and Zupfgeigenhansel. Walter Mossmann recorded with the label Trikont from Munich. While Pläne was linked to the DKP (Holler 2007, p. 134), Trikont had a Marxist-Leninist background (Holler, p. 135). The folk group Fiedel Michel recorded with the label Autogramm from Nottuln. The extent of the popularity of folksingers and Liedermacher was underlined by several having contracts with major labels: in the 1970s Hannes Wader recorded with Philips, Franz Josef Degenhardt and Liederjan with Polydor, and Wolf Biermann with CBS. In the 1980s Zupfgeigenhansel transferred to Musikant, a sub-label of EMI.

Folk music magazines included Song: Chanson Folklore Bänkelsang from 1966-1970, the first mouthpiece of the new movement, which emerged around the activists at the Burg Waldeck Festival. In 1977, Mike Kamp, inspired by the Scottish Sandy Bell's Broadsheet, founded Folk Michel. At the same time, songbooks featuring 1848 songs were brought out by Hannes Wader (1977), Walter Mossmann 
(1978), the Kröhers (1977 and 1991) and Zupfgeigenhansel (1978). Song pamphlets were distributed by movement activists (e.g. Kölner Volksbücher 1978, Buhmann and Haeseler 1980, Student für Europa - Student für Berlin 1980, Westfällisch-Lippische Landjugend 1977), and articles appeared in outlets such as the Folk Magazin and the newspaper of the Club Voltaire in Tübingen. These all contributed to the 'cognitive praxis' of the participants in the West German folk revival and the 'mobilisation' of the memory of the 1848 Revolution.

An example of how this memory was transmitted - and the role of contested ideology in this process - is illustrated by a particular debate in the Club Voltaire Zeitung in 1985. This centred round the interpretation of the famous 'Blutgericht', written from the perspective of the starving weavers of Silesia during their uprising in 1844. The afterword of Mossmann and James Glasbruch 1848 had appeared to criticize Karl Marx for overlooking this song in favour of Heinrich Heine's better known 'Die schlesischen Weber', a poem similarly about the Silesian weavers in 1844 (James and Mossmann, p. 151). In response to this, the folk scene stalwart Dieter Dehm-Lerryn accused James and Mossmann of sectarianism and utopian wishful-thinking, stating that they only preferred 'Das Blutgericht' because it was more radical. ${ }^{18}$ He argued that even unpolitical folk songs (revived at the time by groups such as Zupfgeigenhansel) did a good job of promoting German culture in the face of 'North American imperialism'. ${ }^{19}$ Dehm-Lerryn's argument, however, was ideologically loaded itself, reflecting a bias against commercial popular music. This is reminiscent of the 'sectarian folk-versus-popular dichotomies' which Michael Brocken pinpoints with regard to the British folk revival: 
These assumptions are so built into our understanding of folk music that they appear natural $[\ldots]$ They are human constructions and, like the very history of the folk revival itself, products of social agency [...] not rediscoveries of the products of nature, but political inventions of particular times and places in the twentieth century (p. 2).

Despite such ideological interpretations of folk songs from certain quarters, not all participants of the West German scene were of the same mind-set. Richard Nate states that for many fans the identification with the folk song tradition was more emotional than ideological (1995, p. 89). ${ }^{20}$ As Eckard Holler, co-manager of the Club Voltaire in Tübingen and co-organiser of the Tübingen Festival from 1975 until 1992, remembers, most were not interested in the ideological 'factional battles' which often took place behind the scenes. He states that 'the degree of politicization of the followers of folk music varied considerably. For many it was more a question of alternative cultural identity and lifestyle than of politics'. In terms of the political activists, the scene attempted to represent a 'folk family', inclusive of all ideologies (Holler 2007b, p. 147). This, too, had commonalities with the American folk revival, which, according to Robert Cantwell, represented 'a reconciliation of originally antagonistic socio-political developments, temporarily making common cause against [...] the same adversary, mass or commercial culture' (1996, pp. 355-356.) As Eyerman and Jamison point out, 'social movements are not merely political activities. Perhaps more importantly they provide spaces for cultural growth and experimentation’ (1998, p. 1).

\section{Institutionalisation of German democratic folk song}


While folk song research in West Germany was not centrally funded (as it had been, for example, in the Arbeiterliedarchiv in the GDR), it is clear that by the 1980s democratic cultural heritage, including the memory of the revolution of 1848, was being promoted as part of liberal political culture in the Federal Republic. According to Holler, '[t]he protests of the 1968 era had to a large extent been diverted into institutional channels by the reforms of the Brandt and Scheel government' (2007b, p. 149). This can be seen in the fact that the 1848 songs - alongside German political song in general - began to be used for educational purposes in schools as well as for the teaching of German culture abroad. One example is the cassette of 1848 songs by the group Fortschrott which accompanied Hartmut Flechsig's school workbook Revolution und Romantik in Deutschland (Revolution and Romanticism in Germany) in 1980. Another is the cassettes of German folksong accompanying the Inter Nationes brochure of Max Nyffeler (1983). Inter Nationes was a branch of the Goethe Institute which between 1952 and 2003 distributed promotional material on German culture abroad. These demonstrated how West Germany wished, inwardly and outwardly, to project an image of democratic culture.

While this demonstrated a Germany more at ease with a contentious nationalist past, the context of performance could still be politically contentious. German Liedermacher still risked incurring the wrath of the state if their political activities became too radical. In West Germany, a contentious issue for many of the activists of the folk revival was the 'Radikalenerlass' (radical law) passed in 1972. This threatened people suspected of extreme left-wing political activity with 'Berufsverbot', a work ban which affected civil service professionals such as teachers, of whom there were many in the New Social Movements. ${ }^{21}$ Here again there are parallels with the USA. As we have seen, the Archive of American Folksong and 
the Federal Music Project Archive had played an active role in promoting folk song as national cultural heritage in the United States in the early to mid-twentieth century. Despite this, however, the American folk revival became a victim of the McCarthy anti-communist witch-hunt in the 1950s, resulting in the recording and performance ban of Pete Seeger's highly popular group the Weavers.

A not dissimilar contradiction was experienced in the GDR which, via the work of Busch, Lammel and Steinitz, had promoted revolutionary heritage at institutional level from the state's onset. In the 1960s, the relatively spontaneous folk movement initiated by the aforementioned Perry Friedman was hijacked by the FDJ and turned into a state-monitored Singebewegung, whose mission was to propagate songs in favour of the state. Certain singers and groups, most famously Wolf Biermann in 1976, adapted the political song tradition in a critical way against the state, resulting, in Biermann's case, in an eleven-year performance ban between 1965 and 1976 and ultimately expatriation to West Germany.

\section{The 1848 Tradition in the GDR in the 1980s}

The Inge Lammel collection of 1848 songs from 1957 had reflected the positive mood of the 'Aufbau' years in the GDR. The issue of the defeat of the 1848 revolution was, however, largely left unaddressed. It is interesting to compare this with the reception of the 1848 songs in the GDR folk scene in the 1980s, when the focus shifted to the theme of defeat. In these outgoing years of the GDR state, songs about the failure of the 1848 Revolution served as a subtext acknowledging the end of the socialist dream.

In the GDR folk scene of the 1980s such traditional folk songs offered the chance to air dissatisfactions, the expression of which was otherwise prohibited. In the years after the expatriation of Liedermacher Wolf Biermann in 1976 a new scene of 
young critically-minded singers and groups had emerged, distancing themselves from the pro-state Singebewegung culture they had grown up in as youths (see Robb 2007b). One of the main folk groups was the Folkländer from Leipzig. In 1984 the folk group Wacholder from Cottbus produced a 'Liedertheater' (political songtheatre) production of songs entitled Trotz Alledem. 1848 Revolutionslieder. ${ }^{22}$ As well as containing several texts by the Brandenburg satirical poet Adolf Glaßbrenner which were hitherto ignored in West German reception, the programme included 1848 standards, such as 'Trotz alledem', 'Badisches Wiegenlied' and 'Das Blutgericht'. According to the Wacholder member Matthias Kießling, the group had been drawn to the 1848 repertoire because of the incredibly wide range of themes. They were additionally 'a great peg on which one could hang a multitude of different political grievances' ${ }^{23}$ There was an unspoken understanding with the audience, who knew exactly how to interpret the subtext of the songs. Censors were hesitant to intervene because these were in essence historical texts relating to what the GDR considered as its own revolutionary heritage. For example, the 'Blutgericht' curses the masters who are not accountable to anyone for their actions on earth: 'When you one day after this time / After your life of pleasure / There in that eternity / You will then be accountable'. Another striking theme is censorship and the role of the secret police. ‘Sah ein Fürst ein Büchlein stehn’ (A Prince Saw a Booklet Standing), written by Lebrecht Dreves in 1843, parodies the authorities' fear of subversive literature. The East Berlin audience, as documented on the video recording ${ }^{24}$, seeing their own situation clearly mirrored regarding the surreptitious exchange of politically controversial books, laughed heartily at the lines: 'And the good prince forbade / Booklet in the country / Booklet however didn’t suffer / Was passed around like hot loaves / From hand to hand'. Fallersleben's 'Unsere Fürsten' (Our Princes) is 
performed in such a way as to allude to Stasi surveillance in the GDR, its effects on freedom of speech and the unchanged relationship (despite socialism) between master and servant: 'It gets worse from day to day, / Silence is our only right. / It's not proper for subjects to complain, / The servant must obey the master.' The lines 'Our brothers are expelled / The police are above the law' would be interpreted as a sly reference to the unlawful confinement of GDR political prisoners who subsequently were pushed out to West Germany (Wacholder 1984).

If the Lammel collection of 1957 emphasised the optimistic metaphor of ‘Aufwachen’ (Awaken), this is notably absent from the Wacholder song programme. Indeed Wacholder chose songs with the opposite metaphor of sleep, denoting a land in stagnation. Herwegh's 'Wiegenlied' (Lullaby), for example, ironically invites Germany to sleep on in the comfort of its religious and literary icons. But it is in 'Badisches Wiegenlied' that the theme of sleep is most prominent. Wacholder's musical accompaniment evokes the melancholy mood of dashed ideals and the retreat into a private, inner world. This reflected the pessimism in the GDR in the early 1980s, when no one could have foreseen the changes that were to come later in the decade. Lines such as ‘And if you don’t sleep peacefully / the Prussian will close your eyes for you' and 'We all have to keep quiet' were able to be interpreted as a reference to secret police observation. For Kießling 'Badisches Wiegenlied’ was ‘the biggest hit’ of their programme.

In Wacholder's performance of a 'Trotz alledem' parody, written by their GDR 'Liedertheater’ colleagues Hans-Eckardt Wenzel and Steffen Mensching, the rebellious spirit of 1848 provides the reference point against which the stagnation of the revolutionary ideal in the present is measured: the 'Trotz alledem' motif relates to the complete absence in the GDR of the revolution which Marx had once predicted: 
'the chilling, cold winter wind / blasts in our face for all that'. Even if GDR society can now boast of material comforts in as much as 'the fridge hums' and the quality of life in the Workers' and Peasants' State enables the ordinary people to drink sparkling wine, these conditions are at the same time petit-bourgeois to the extent that the revolutionary heritage has - metaphorically - been drunk dry along with the schnapps. The lines 'For all stupidity, fraud and all that / no one other than ourselves / can set us free from all that' relate to the people who through their own failings have spoiled the socialist experiment - the leading politicians as well as the normal citizens.

\section{Conclusion}

With the fall of the Berlin Wall in 1989, the dismantling of the communist block and the unification of Germany in 1990, the leftist ideological dimension of the folk revival (such as in the above dispute between Mossmann and Deym Lerryn) receded into the background. Through efforts of folk scene and academics from the 1950s onwards, Germany had reconciled the tradition of rebellious 1848 songs with its democratic image of itself. In West Germany, songs which had once represented an act of defiance against conservative post-war establishment had now become assimilated into mainstream culture (albeit a markedly different area of culture from commercial German Volkslieder). The context for democratic folk song reception was the music club and folk festival culture which had grown up in the 1970s and 1980s. The folk musicians of the GDR, who had questioned their state's assumption to be the natural inheritor of the 1848 revolutionary song tradition, took stock of the new situation, re-orientating themselves in a new capitalist, united German landscape (see Robb 2007C, pp. 255-265). In 1990 the folk scenes of East and West joined together 
at the Tanz- und Folkfestival Rudolstadt, which was to grow into the largest folk, dance and world music festival in Germany. In 1998 the West German magazine Folk-Michel fused with the East German Folksblatt to become Folker!

In this new national and political context, the $150^{\text {th }}$ anniversary of the 1848 Revolution was celebrated in 1998. Several compilation CDs of 1848 songs were released including two from old stalwarts of the folk scene, east and west: the Leipziger Folksessions’ 18 aus 48. Das Beste von der Barrikade (18 out of 48. The Best from the Barricade) by a new extended line-up of the group Folkländer, and the German Folk Song Archive’s weil jetzt die Freiheit blüht, recorded by various artists including Liederjan, Hein \& Oss Kröher, Wolf Biermann, Wacholder and Duo Sonnenschirm.

The 1848 revolutionary songs, born out of a nineteenth century nationalist movement whose aims were anti-establishment, are themselves an illustration of Bohlman's argument that nationalism in song has 'many shades', not all typically conservative and reactionary. After a century and a half of suppression, virtual extinction, revival, selection and ideological shaping, a repertoire of Vormärz and 1848 songs had asserted itself as democratic heritage in the newly unified German state. This had been achieved by musicians and academics in the folk revivalist movements of both West Germany and the GDR, all actively involved in the mobilisation of this forgotten song tradition..

\section{Bibliography}

Adamek-Schyma, B and Tzschaschel, S. 2006. 'Populäre Volksmusik - regional verwurzelt?’ (Leipzig: Leibniz-Institut für Länderkunde) http://archiv.nationalatlas.de/wp-content/art_pdf/Band12_104-107_archiv.pdf

Bluestein, G. 1972. The Voice of the Folk. Folklore and American Literary Theory (Amherst: University of Massachusetts Press). 
Bohlman, P. V. 1988. 'Traditional Music and Cultural Identity: Persistent Paradigm in the History of Enthnomusicology', Yearbook for Traditional Music 20, pp. 26-42.

Bohlman. P. V. 2004. The Music of European Nationalism: Cultural Identity and Modern History (Santa Barbara: ABC-CLIO).

Böning, H. 2004. Der Traum von einer Sache. Aufstieg und Fall der Utopien im politischen Lied der Bundesrepublik und der DDR (Bremen: Edition Lumière).

Brocken, M. 2003. The British Folk Revival 1944-2002 (Aldershot: Ashgate).

Buhmann H. and Haeseler H. (ed.) 1980. Das kleine dicke Liederbuch (Marburg: Self-Publication).

Busch E. (ed.) 1949. Internationale Arbeiterlieder (Berlin: Verlag Lied der Zeit).

Cantwell R. 1996. When We Were Good: The Folk Revival (Cambridge, Massachusetts: Harvard University Press).

Cohen, R. D. 2006 Folk Music. The Basics (New York: Routledge).

Deutsches Volksliedarchiv. 1938. Oberschlesische Volkslieder [Landschaftliche Volkslieder] (Cassel: Bärenreiter).

Erk, L. and Böhme F. M. (ed.) 1893-1894. Deutscher Liederhort. 3 volumes (Leipzig: Breitkopf und Härtel).

Eyerman R. and Jamison A. 1998. Music and Social Movements. Mobilizing Traditions in the Twentieth Century (Cambridge: Cambridge University Press).

Flechsig, H. 1980. Revolution und Romantik in Deutschland. Politische und andere Lieder aus der Zeit von 1813 bis 1848. Schülerheft (Regensburg: Gustav Bosse Verlag).

Friz T. and Schmeckenbecher E. (Zupfgeigenhansel) (ed.) 1978. Es wollt ein Bauer früh aufstehn... 222 Volkslieder (Dortmund: Verlag Pläne).

Gitlin, T. 1987. The Sixties (New York: Bantam).

Harker, D. 1985. Fakesong. The Manufacture of British 'folksong' 1700 to the Present Day (Milton Keys and Philadelphia: Open University Press).

von Herder, J. C. 1778 and 1779. Volkslieder nebst untermischten anderen Stücken, vol. 1 and 2 (Leipzig: Weygandsche Buchhandlung). 
Hobsbawm, E. 1983. 'Introduction: Inventing Traditions', in The Invention of Tradition, ed. E. Hobsbawm and T. Ranger (Cambridge: Cambridge University Press), pp. 1-14.

Holler, E. 2007a. 'The Burg Waldeck Festivals, 1964-1969' in Protest Song in East and West Germany, ed. D. Robb (Rochester/NY: Camden House), pp. 97-132.

Holler E. 2007b. 'The Folk and Liedermacher Scene in the Federal Republic', in Protest Song, ed. D. Robb, pp. 133-168.

James B. and Mossmann W. 1983. Glasbruch 1848. Flugblätter und Dokumente einer zerbrochenen Revolution (Darmstadt and Neuwied: Luchterhand).

Kaiser, K. 1952. Die Achtundvierziger. Ein Lesebuch für unsere Zeit (Weimar: Thüringer Volksverlag).

Kinsley J. (ed.) 1968. The Poems and Songs of Robert Burns, vol 2 (Oxford: Clarendon Press).

Kirchenwitz L. 1993. Folk Chanson und Liedermacher in der DDR. Chronisten, Kritiker, Kaisergeburtstagssänger (Berlin: Dietz Verlag).

Kölner Volksbücher (ed.) 1978. 1848. Lieder der Revolution (Cologne: SelfPublication).

Kröher H. and Kröher O. (ed.) 1977. Das sind unsere Lieder. Ein Liederbuch (Frankfurt am Main: Büchergilde Gutenberg.).

Kröher H. and Kröher O. (ed.) 1991. Die Liederpfalz. Ein Liederbuch (Landau: Pfälzische Verlagsanstalt).

Lammel I. (ed.) 1957. Das Lied im Kampf Geboren! Heft 1. Lieder der Revolution von 1848 (Leipzig: VEB Friedrich Hofmeister).

Leeder K. 1996. Breaking Boundaries. A New Generation of Poets in the GDR (Oxford: Clarendon Press).

Lomax J. A. and Lomax A. (ed.) 1934. American Ballads and Folksongs (New York: MacMillan Co.).

Lomax J. A. and Lomax A. (ed.) 1936. Negro Folk Songs as sung by Lead Belly (New York: MacMillan Co.).

Lomax J. A., Lomax A., Seeger C. and Crawford Seeger R. (ed.) 1947. Folksong USA (New York: Duell, Sloan and Pearce).

Mackinnon, N. 1994. The British Folk Scene. Musical Performance and Social Identity (Buckingham and Philadelphia: Open University Press). 
Mahnert D. and Stürmer H. 2008. Zappa, Zoff und Zwischentöne. Die Internationalen Essener Songtage 1968 (Essen: Klartext).

Meier J. et al. 1935-1996. Deutsche Volkslieder mit ihren Melodien: Balladen . 10 Volumes. (Berlin: De Gruyter).

Mensching S. and Wenzel H-E. 1990. 'Entwürfe einer anderen Welt: ein Gespräch mit Frauke Meyer-Gosau’, MachtApparat-Literatur, Text + Kritik 108, pp. 86-94

Mossmann W. and Schleuning P. 1980 Alte und neue politische Lieder. Entstehung und Gebrauch. Texte und Noten (Reinbek bei Hamburg: Rowohlt Taschenbuch).

Mossmann. W. 1985. 'Volkslieddiskussion', Club Voltaire Zeitung (Jan/Feb), p. 112.

Munro, A. 1984. The Folk Music Revival in Scotland (London: Kahn and Averill).

Nate, R. 1994 “"Nachsehen, was mit der alten Linde wär...” Zum Umgang mit dem Volkslied in der Folkbewegung der sechziger und siebziger Jahre'. Jahrbuch für Volksliedforschung 39, pp. 76-95.

Nyffeler M. 1983. Liedermacher in der Bundesrepublik Deutschland (Bonn: Inter Nationes).

Otto U. 1982. Die historisch-politischen Lieder und Karikaturen des Vormärz und der Revolution von 1848/1849 (Cologne: Pahl-Rugenstein Hochschulschriften).

Pinkert-Sältzer, I. 1997. German Songs. Popular, Political, Folk, and Religious (New York: Continuum).

Probst-Effah, G. 1995. Lieder gegen das 'Dunkel in den Köpfen': Untersuchungen zur Folkbewegung in der Bundesrepublic Deutschland (Essen: Verlag Die Blaue Eule).

Robb, D. 2007a. 'The Reception of Vormärz and 1848 Revolutionary Song in West Germany and the GDR', in Protest Song in East and West Germany, ed. D. Robb (Rochester/NY: Camden House) pp. 11-33.

Robb D. 2007b. 'Political Song in the GDR. The Cat-and-Mouse Game with Censorship and Institutions’, in Protest Song, pp. 227-254.

Robb, D. 2007c. 'The Demise of Political Song and the New Discourse of Techno in the Berlin Republic’, in Protest Song, pp. 255-278.

Robb D. 1998. Zwei Clowns im Lande des verlorenen Lachens. Das Liedertheater Wenzel \& Mensching (Berlin: Ch. Links Verlag).

Robb D. and John E. 2011. ““A Man's a Man for A' That” and “Trotz alledem”: Robert Burns, Ferdinand Freiligrath and their Reception in the German Folksong Movement', Modern Language Review 106, pp. 17-46. 
Robb D. and John E. 2008-2013. 'Lieder der Revolution von 1848 und ihre Rezeptionsgeschichte in Deutschland', Historisch-Kritisches Liederlexikon, ed. E. John (http://www.liederlexikon.de/ueber_liederlexikon_de/projekte/ahrc-dfg_projekt)

Rodnitsky, J. 2006. 'The Decline and Rebirth of Folk-Protest Music' in The Resisting Muse: Popular Music and Social Protest, ed. I. Peddie (Burlington: Ashgate), pp. 1729.

Rosenberg, N. V. (ed.) 1993. Transforming Tradition: Folk Music Revivals Examined (Urbana: University of Illinois Press ).

Rosenthal R. and Flacks R. 2012. Playing for Change. Music and Musicians in the Service of Social Movements (Boulder and London: Paradigm).

Seeger P. 1965. 'Whatever Happened to Singing in the Unions', Sing Out (15 May), pp. 28-31.

Steinitz W. 1955 and 1962. Deutsche Volkslieder demokratischen Charakters aus sechs Jahrhunderten (Berlin: Akademie Verlag).

van Stekelenburg D. 1993. “"Trotz alledem!” - Die Revolution zersungen. Von der Epigonalität politischer Aktualität’, Amsterdamer Beiträge zur neueren Germanistik, 36, pp. 377-407.

Student für Europa - Student für Berlin (ed.) 1980. Lieder-Karren (Bad Soden: SelfPublication).

Verein Verlag Neue Zeit (ed.) 1978. Lieder der Revolution 1848 (Kiel: SelfPublication).

Wader H. 1977. Lieder (Frankfurt am Main: Zweitausendeins).

Westfällisch-Lippischen Landjugend (ed.) 1977. Liederbuch (Münster: SelfPublication).

Widmaier, T. 2008. 'Ob wir rote, gelbe Kragen (Bürgerlied)', Historisch-Kritisches Liederlexikon, ed. E. John.

http://www.liederlexikon.de/lieder/ob_wir_rote_gelbe_kragen

Willert P. 1960. 'Ein Disziplinverfahren um das "Freiheitslied vom treuen Robert Blum”'. Volkskunst. Monatsschrift für das künstlerische Volksschaffen 9, 7, pp. 2729.

Williams, R. 1977. Marxism and Literature (Oxford: Oxford University Press).

\section{Discography}


Franz Josef Degenhardt, 'Die alten Lieder', Der Senator Erzählt. Polydor, 237834. 1968.

Fiedel Michel, No. 4. Deutsche Lieder und Tänze aus den letzten 5 Jahrhunderten. Autogram, ALLP-199. 1975.

Fortschrott, Revolution und Romantik in Deutschland. Politische und andere Lieder aus der Zeit von 1813 bis 1848. Gustav Bosse, BE 2192 MC. 1980.

Fredrik und Uli [Fredrik Vahle und Ulrich Freise], Wir Bürgermeister und Senat. Da Camera, SM 95012. 1968.

Hein \& Oss [Kröher], Deutsche Lieder.1848/49. Songbird, 1 C 062-31 126. 1974.

Leipziger Folksessions, 18 aus 48. Das Beste von der Barrikade. Heideck, HD98-3. 1998.

Liederjan, Mädchen, Meister, Mönche. Polydor, 2371876. 1978.

Walter Mossmann, 'Badisches Wiegenlied', Konzert für Pitter. Venceremos, EV 7700. 1977.

Peter Rohland, 48er Lieder -- Lieder deutscher Demokraten. Teldec/Resco, T 75508. 1967.

Dieter Süverkrüp, 1848 - Lieder der deutschen Revolution. Pläne, S 11102. 1973.

Various Artists, Glasbruch 1848. Trikont, US-08-0114. 1984.

Various artists, Lieder zur vergessenen Badischen Revolution 1848/49. Dokumentation zum Volksfest vom 26.-27. Mai 1978 in Freiburg. Trikont US-48. 1979.

Various Artists, Liedermacher in der Bundesrepublik Deutschland. Inter Nationes, M 97 BSA 15. 1983.

Various Artists, ...weil jetzt die Freiheit blüht: Lieder von der Revolution von 1848/49. Südwest Records/Deutsches Volksliedarchiv, SWR104-98. 1998.

Hannes Wader, Hannes Wader singt Arbeiterlieder. Philips/Phonogram, 6305342. 1977.

Hannes Wader, Volkssänger. Philips, 6305 254. 1975.

Videos

Wacholder, Trotz Alledem. 1848 Revolutionslieder. Berlin: Lied-Zentrum der Akademie der Künste der DDR, 1984. 
${ }^{1}$ As Bluestein writes: 'Herder's concern with the relationship between folklore, folksong, and nationalism has led to a curious misconstruction of his major intentions.' p. 7.

2 H. Sulzer, 'Hecker Hoch', in Demokratisches Revolutionsgebrüll, oder Hochverrathslieder gesungen von dem Träger eines Freischärlerhutes (Strasbourg: Huder [1848]), pp. 4-5.

${ }^{3}$ For example, traces of an oral tradition of the Robert Blum song 'Leute höret die Geschichte' were only first documented in Braunschweig in 1907. See Robb and John (2008-2013).

${ }^{4}$ Steinitz, in his process of selection, was additionally restricting himself to songs of the 'werktätiges Volk' (working people), which these bourgeois poets were not. This, however, did not stop the new folk singers of the 1960s and 1970s incorporating the latter poets' songs in their 1848 repertoires. These included Herwegh's ‘Zu Frankfurt an dem Main' (At Frankfurt on Main), Freiligrath's ‘Trotz alledem' and Hoffmann von Fallersleben's 'Ausgelitten, ausgerungen' (Long Suffering and Wrung Out) (see Robb and John, 2013).

${ }^{5}$ It is worth pointing out that Germany was not alone in having preserved a kitsch folk culture. The Scottish folk revival of the 1960s was amongst other things a reaction against the 'Scottish popular music' embodied by the likes of well known TV entertainers Kenneth MacKellar, Moira Anderson and Peter Morrison. See Munro (1984), p. 42. The difference to Germany, however, is that many of the songs those people sang (including those of Burns which were associated with polished drawing rooms and piano accompaniment) could be repackaged and sung in a modern folk style with antiestablishment connotations.

${ }^{6}$ Within his concept of 'democratic' song Steinitz pursued his own process of selection by restricting himself to songs of the 'werktätiges Volk' (working people). A consequence of which was his exclusion of the 1848 revolutionary songs of the bourgeois poets Heinrich Hoffmann von Fallersleben, Ferdinand Freiligrath and Georg Herwegh. This, however, did not stop the new folk singers of the 1960s and 1970s including the latter poets' songs in their repertoires (see Robb and John, 2013).

${ }^{7}$ One result had been the movement away from a national focus which, as Bohlman writes, was reflected in the post-war activity of the International Folk Music Council (1988, p. 36).

${ }^{8}$ In the literary sphere this was mirrored by the nurturing of the Classical 'Erbe' (Heritage) of Goethe and Schiller which stemmed from the GDR's claim to be the legitimate cultural successor of all progressive and humanist elements in the German tradition.

${ }^{9}$ In the nineteenth century and up until this point the two known musical accompaniments for 'Trotz alledem' had been the German folk tune 'Als Noah aus dem Kasten war' and another melody written by Heinrich Jäde. See Robb and John, “'A Man’s a Man for a' that” and “Trotz alledem”: Robert Burns, Ferdinand Freiligrath and their reception in the German Folksong Movement', Modern Language Review, 156/1, pp. 17-46, 2011, here pp. 36-37.

${ }^{10}$ See full German text at Robb and John. 2008-2013:

http://www.liederlexikon.de/lieder/trotz_alledem/editionc

${ }^{11}$ This last verse is the original version of the Burns' poem of 1795. See James Kinsley (ed.) The Poems and Songs of Robert Burns, vol 2 (Oxford: Clarendon Press 1968), p. 762 (no. 482).

${ }^{12}$ Indeed the shortening of the phrase 'trotz alledem' to 'trotz allem' in every line except the first line of the refrain and the slight word alterations of Freiligrath's translation of Burns' last verse could well be the indication of an oral tradition.

${ }^{13}$ Various artists, Lieder zur vergessenen Badischen Revolution 1848/49. Dokumentation zum Volksfest vom 26.-27. Mai 1978 in Freiburg, LP, Trikont US -48 (1979). See also: Glasbruch 1848, LP, Trikont US-08-0114 (1984). Other releases contained individual songs from the Vormärz and the 1848 Revolution. See Hannes Wader, Volkssänger, LP, Philips 6305254 (1975); Fiedel Michel, No. 4. Deutsche Lieder und Tänze aus den letzten 5 Jahrhunderten, LP, Autogram ALLP-199 (1975); Liederjan, Mädchen, Meister, Mönche, LP, Polydor 2371876 (1978). 
14 'Das Blutgericht', see Steinitz, Deutsche Volkslieder vol. I, p. 232. English translation by Sabine Toner in Inke Pinkert-Sältzer, German Songs. Popular, Political, Folk, and Religious (New York: Continuum, 1997), p. 26.

${ }^{15}$ For further parodies of 'Trotz alledem' in the West German New Social Movements and in the GDR see Robb and John, '"A Man's a Man for a' that” and “Trotz alledem”, pp. 38-46.

${ }^{16}$ Even the GDR folk scene would use the DVA as a resource although the musicians were not permitted to leave the GDR to visit it. Jürgen Wolff from the Leipzig group Folkländer, for example, was in regular written contact with Barbara James.

${ }^{17}$ GDR dissident singer Wolf Biermann had been expatriated from the state in 1976 and was now living and performing in West Germany.

18 'Volkslieddiskussion', Club Voltaire Zeitung 112 (Jan/Feb 1985), p. 12.

19 'Volkslieddiskussion', p. 12.

${ }^{20}$ In this respect Nate (1994) makes a comparison with the Wandervogel movement of the early twentieth century.

${ }^{21}$ Eckard Holler writes about the dilemma he encountered as a teacher whilst also being a member of the SDAJ (Sozialistische Deutsche Arbeiterjugend), the youth organization of the DKP (Deutsche Komunistische Partei). He chose to resign from the SDAJ which resulted in a split between them and the Club Voltaire in Tübingen, which he co-mananged, in late 1974. See Holler, 'The Folk and Liedermacher Scene in the Federal Republic', p. 153.

${ }^{22}$ Wacholder, Trotz Alledem. 1848 Revolutionslieder (unpublished manuscript and video, Berlin 1984). Subsequent unreferenced quotations from songs are from this production. The video can be viewed in the Akademie der Künste in Berlin as part of the 'Liedertheater' collection of the former 'LiedZentrum' of the GDR.

${ }^{23}$ Personal Interview with Matthias Kießling, 26 November 2003.

${ }^{24}$ See Wacholder video of Trotz Alledem (1984). 